\title{
Balgachernes occultus, a new genus and species of pseudoscorpion (Pseudoscorpiones: Chernetidae) associated with balga (Xanthorrhoea preissii) in south-western Australia, with remarks on Austrochernes and Troglochernes
}

\author{
Mark S. Harvey \\ Department of Terrestrial Zoology, Western Australian Museum, 49 Kew Street, Welshpool, Western \\ Australia 6106, Australia; Adjunct: School of Biological Sciences, University of Western Australia, \\ Crawley, Western Australia 6009, Australia. \\ Email mark.harvey@museum.wa.gov.au
}

\begin{abstract}
A new genus and species of chernetid pseudoscorpions, Balgachernes occultus, is described from south-western Western Australia. It appears to have the greatest similarity to Austrochernes, but differs by the widely spaced (diastemodentate) chelal teeth, the slightly gaping chelal fingers and the position of trichobothrium est which is situated closer to esb than to et. All specimens have been collected from balga, Xanthorrhoea preissii, a species of grass tree. The genus Austrochernes Beier, 1932 is redescribed based on the male syntypes of the only known species, A. australiensis (With, 1905), which clearly shows that Austrochernes is a new senior synonym of Troglochernes Beier, 1967. The following species are newly transferred to Austrochernes: T. cruciatus Volschenk, 2007, Sundochernes dewae Beier, 1967, S. guanophilus Beier, 1967, T. imitans Beier, 1969, S. novaeguineae Beier, 1965, and T. omorgus Harvey and Volschenk, 2007.
\end{abstract}

KEYWORDS: taxonomy, morphology, grass trees, Arachnida

urn:Isid:zoobank.org:pub:3ABB6862-1D7A-42CB-9F54-BA6547DBDA0F

\section{INTRODUCTION}

The Chernetidae is by far the most diverse pseudoscorpion family in the world at the generic level, with 117 genera currently recognised (Harvey 2013), which constitutes a quarter of the generic diversity of the entire order. However, the higher classification is poorly resolved, with two subfamilies, Lamprochernetinae and Goniochernetinae, that can be defined with synapomorphies: the presence of T-shaped spermathecae in the female genitalia of Lamprochernetinae, and an angulate posterior margin of the carapace of Goniochernetinae (Harvey 1995). The third subfamily, Chernetinae, appears to represent a paraphyletic assemblage of genera that cannot be placed in either of the other subfamilies (Harvey 1995). Chernetids occupy a wide variety of terrestrial habitats including leaf litter, soil, humus, caves, and under the bark of trees and logs. Some species have close associations with other animals, as commensals in the nests and pelage of mammals (e.g. Beier 1948a; Durden 1991; Finlayson et al. 2015; Harvey et al. 2012; Muchmore 1971), in the nests and feathers of birds (Turienzo et al. 2010), or on arthropods (e.g. Beier 1948a; Muchmore 1971). Others have close associations with certain habitats with notable examples including Dendrochernes cyrneus (L. Koch, 1873) with old trees, particularly oaks, in Europe (e.g. Esser 2011; Jones 1980), Anthrenochernes stellae Lohmander, 1939 from decaying wood in old hollow trees in northern Europe (Gärdenfors and Wilander 1995; Holmen and Scharff 2008), Dinocheirus arizonensis (Banks, 1901) with cacti and succulents in arid North America (Banks 1901; Pfeiler et al. 2009), Chelodamus spp. with bromeliads in Central America (Mahnert 1994; Muchmore 1984) and Attaleachernes thaleri Mahnert, 2009 with palm trees in Brazil (Mahnert 2009).

The present study reports on a new genus of Chernetidae that has been collected in south-western 
Australia exclusively from the tightly packed leaf-bases of the balga, Xanthorrhoea preissii Endl. The genus Xanthorrhoea is endemic to Australia and is the only member of the monocot family Xanthorrhoeaceae. Xanthorrhoea preissii (Figure 1) is restricted to south-western Australia where it is widespread (see https://florabase.dpaw.wa.gov.au/browse/profile/1256; accessed 25 February 2018). The trunks are up to $3 \mathrm{~m}$ high, with a total height including the foliage of $5 \mathrm{~m}$. The leaves are extremely thin and form tight clusters which grow directly from the trunk (Figure 2). Balga harbour a variety of invertebrate animals that shelter, feed and breed within the living and dead leaves. A recent study examining the fauna associated with balga near Perth, Western Australia found that some invertebrates survived fire events by using the grass tree (balga) crown as a refugium that experiences lower temperatures during fire than other parts of the plant (Brennan et al. 2011). Among the fauna were three pseudoscorpion species, a species of Chernetidae, a species of Protochelifer Beier, 1948 (family Cheliferidae), and a species of Protogarypinus Beier, 1954 (family Garypinidae). While the cheliferid and garypinid were represented by single specimens, the chernetid was frequently collected. The chernetid, which is the subject of this study, was found to resemble the Australian genera Austrochernes Beier, 1932 and Troglochernes Beier, 1969, but differs in some important morphological features suggesting that it belongs to a new genus.

In conjunction with the description of the chernetid species collected from balga, a study was made of the type species of Austrochernes, A. australiensis (With, 1905), which was described from two adult males from eastern Australia (With 1905). Although species of the genus were originally reported to possess a tactile seta on tarsi III and IV (Beier 1932, 1933), this is not true of the type species, A. australiensis (Beier 1966a, b; With 1905). The lack of a tactile seta is confirmed in the type series, and all of the other major taxonomic features conform to the genus Troglochernes, which is here regarded as its junior synonym.

\section{MATERIAL AND METHODS}

The material examined of the new species is lodged in the Western Australian Museum, Perth (WAM), and the type material of Austrochernes australiensis is lodged in the Natural History Museum, London (BMNH). The specimens were studied using temporary slide mounts prepared by immersion of the specimen in lactic acid at room temperature for several hours to days, and mounting them on microscope slides with $10 \mathrm{~mm}$ coverslips supported by small sections of $0.25,0.35$ or $0.5 \mathrm{~mm}$ diameter nylon fishing line. After study the specimens were rinsed in water and returned to $75 \%$ ethanol with the dissected portions
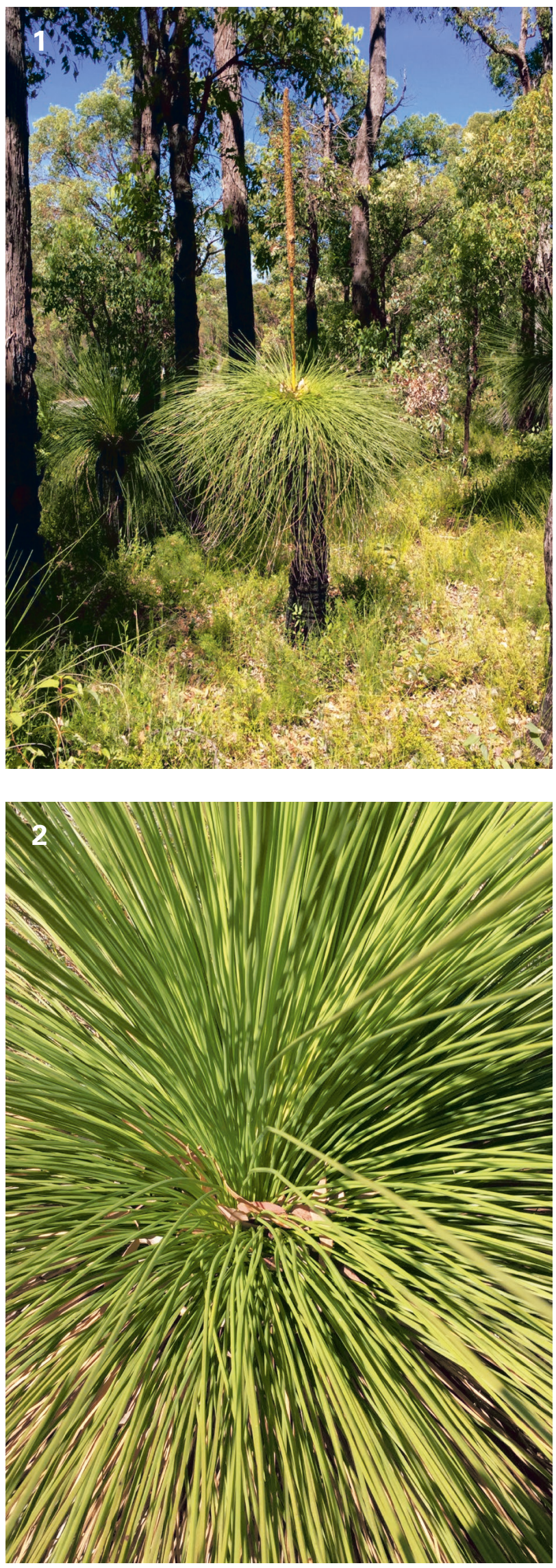

FIGURES 1-2 A balga (Xanthorrhoea preissii) at Brookton Highway, Western Australia: 1, entire plant with a single inflorescence; 2 , crown showing tightly packed leaf-bases. 
placed in $12 \times 3 \mathrm{~mm}$ glass genitalia microvials (BioQuip Products, Inc.). Specimens were examined with a Leica MZ-16A (Wetzlar, Germany) dissecting microscope, and an Olympus BH-2 (Shinjuku, Tokyo) compound microscope, and illustrated with the aid of a drawing tube attached to the compound microscope. Measurements were taken at the highest possible magnification using an ocular graticule. A female specimen of the new species was critical point dried, gold coated and imaged using a Hitachi TM3030 Plus scanning electron microscope.

Terminology and mensuration mostly follow Chamberlin (1931), with the exception of modifications to the nomenclature of the pedipalps and legs, the terminology of the trichobothria (Harvey 1992b), chelicera (Judson 2007) and faces of the appendages (Harvey et al. 2012). The following abbreviations are used: chelal trichobothria: fixed finger, $e b$, externo-basal trichobothrium; esb, externo-subbasal trichobothrium; est, externo-subterminal trichobothrium; et, externo-terminal trichobothrium; $i b$, interno-basal trichobothrium; isb, interno-subbasal trichobothrium; ist, interno-subterminal trichobothrium; it, internoterminal trichobothrium; movable finger, $b$, basal trichobothrium; $s b$, subbasal trichobothrium; $s t$, subterminal trichobothrium; $t$, terminal trichobothrium; cheliceral setae: ebs, externobasal seta; es, external seta; $g s$, galeal seta; is, interior seta; $l s$, laminal seta; $s b s$, subbasal seta.

\section{SYSTEMATICS}

\section{Family Chernetidae Menge, 1855}

\section{Subfamily Chernetinae Menge, 1855}

\section{Genus Balgachernes gen. nov.}

$$
\text { urn:Isid:zoobank.org:act:50C02F7D-DF13-4130-9F21- }
$$
47BB1C895833

\section{TYPE SPECIES}

Balgachernes occultus sp. nov.

\section{DIAGNOSIS}

Balgachernes differs from all other chernetid genera by the following combination of characters: trichobothrium est much closer to esb than to et; isb much closer to ist than it (Figure 14); 1 pair of short spermathecae (Figure 22); patellae and tibiae III and IV without pseudotactile setae (Figure 19); tarsi III and IV without tactile seta (Figure 19); cheliceral rallum composed of 4 blades (Figure 10); chelal fingers slightly gaping (Figures 14-15), and with slightly diastemodentate teeth (Figure 15). Detailed comparisons with similar genera can be found below.

\section{DESCRIPTION}

\section{Adults}

Chelicera (Figure 9): hand with 5 or 6 setae, setae es, $l s$ and $i s$ acuminate, $b s$ ', $b s$ " and $s b s$ dentate; movable finger with 1 subdistal seta; galea present, with several distal rami; lamina exterior present; serrula exterior connected to chelicera finger for most of length; serrula interior modified to form velum; rallum comprised of 4 blades, 2 anterior blades with spinules on leading face, others without spinules (Figure 10).

Pedipalp (Figure 13): fixed chelal finger with 8 trichobothria, movable chelal finger with 4 trichobothria (Figure 14): $e b$ and $e s b$ situated basally; est situated closer to esb than to $e t ; i b$ and ist subbasally; it situated midway between et and est; isb situated closer to ib and $i s t$ than to $i t ; b$ and $s b$ situated basally; st situated slightly closer to $s b$ than $t ; t$ midway between $s t$ and tip of finger. Chelal teeth (Figure 15) mostly diastemodentate, but basal teeth tending to be juxtadentate, most teeth triangular with pointed tips; only 1 accessory tooth, on retrolateral margin of fixed finger; fingers slightly curved, forming a distinct gap (Figures 14-15); venom apparatus only present in movable chelal finger; venom duct long, terminating midway between $t$ and $s t$; nodus ramosus slightly inflated (Figure 15).

Cephalothorax: carapace (Figure 8) with 2 distinct furrows, posterior furrow much closer to posterior margin of carapace than to anterior furrow; with 1 pair of small, very faint eye-spots; posterior margin straight. Manducatory process somewhat pointed, with 2 or 3 apical setae and 1 sub-oral seta; median maxillary lyrifissure situated medially.

Legs: junction between femora and patellae I and II strongly oblique (Figure 18); tarsi III and IV without tactile seta (Figure 19); tarsi with single raised slit sensillum; subterminal tarsal seta arcuate and acute; arolium slightly shorter than claws.

Abdomen (Figures 3-6): tergites I-X with median suture line; sternites IV-X with medial suture line; spiracular plates each with 1 seta; $\hat{\sigma}$ sternite II with setae arranged in inverted-U over median third, sternite III with setae widely scattered (Figure 20); 9 sternite II with setae arranged in inverted-U, sternite III with setae arranged on posterior edge (Figure 21); pleural membrane irregularly longitudinally striate, without setae.

Genitalia: male of typical chernetid morphology; female with 2 lateral cribriform plates, and a single pair of short, thick spermathecae, each slightly bulbous (Figure 22).

\section{Tritonymphs}

Chelicera: hand with 5 setae, setae es, $l s$ and is acuminate, $b s$ and $s b s$ dentate; movable finger with 1 subdistal seta; galea present, with several distal rami.

Pedipalp: fixed chelal finger with 7 trichobothria, movable chelal finger with 3 trichobothria (Figure 16): 
$e b$ and $e s b$ situated subbasally; est situated closer to $e s b$ than to $e t ; i b$ and ist subbasally; it situated midway between et and est; st situated midway between $t$ and $b$. Chelal teeth mostly diastemodentate; 1 accessory tooth, on retrolateral margin of fixed finger; fingers slightly curved, forming a distinct gap; venom duct terminating near $t$.

Cephalothorax: carapace with 2 furrows, anterior furrow shallow, posterior furrow closer to posterior margin of carapace than anterior furrow; with 1 pair of faint eye-spots.

Legs: much as in adults.

Abdomen: tergites I-X and sternites II-X with median suture line.

\section{Deutonymphs}

Chelicera: hand with 5 setae, setae es, $l s$ and is acuminate, $b s$ and $s b s$ dentate; movable finger with 1 subdistal seta; galea present, with 3 distal rami.

Pedipalp: fixed chelal finger with 6 trichobothria, movable chelal finger with 2 trichobothria (Figure 17): $e b$ situated subbasally; est situated closer to esb than to et; $i b$ and ist subbasally; it closer to est than to est; $t$ situated slightly closer to $b$ than to tip of finger. Chelal teeth slightly diastemodentate; without accessory teeth; fingers slightly curved, forming a distinct gap; venom duct terminating near $t$.

Cephalothorax: carapace with 2 shallow furrows, posterior furrow closer to posterior margin of carapace than anterior furrow; with 1 pair of faint eye-spots.

Legs: much as in adults.

Abdomen: tergites I-X and sternites II-X with median suture line.

\section{REMARKS}

Balgachernes most closely resembles those genera that have four blades in the cheliceral rallum and lack a tactile seta on legs III and IV. Although the number of rallar blades has been used as a primary character to define the tribes Chernetini (2-3 blades) and Hesperochernetini (4 blades) within the subfamily Chernetinae (Beier 1932), this arrangement was abandoned by Muchmore (1972) when he found that species of Chernes Menge, 1855 most frequently have four rallar blades, just like species of Hesperochernes Chamberlin, 1924. Muchmore (1972) also noted that accurately counting the number of rallar blades is not always possible, especially if the chelicera is not dissected from the body. A further complication is the lack of any mention of the rallum in the description of some genera, including Acanthicochernes Beier, 1964 from the Solomon Islands, Hebridochernes Beier, 1940 from the West Pacific and Phaulochernes Beier, 1976 from New Zealand (Beier 1940, 1964b, 1976). Nevertheless, comparing Balgachernes with those genera that are known to possess four blades in the cheliceral rallum and lack a tactile seta on legs
III and IV, however imprecise, is the best solution. These include Chernes from the Holarctic region; Atherochernes Beier, 1954, Cocinachernes Hentschel and Muchmore, 1989, Gigantochernes Beier, 1932, Hesperochernes, Illinichernes Hoff, 1949, Maxchernes Feio, 1960, Mirochernes Beier, 1930, Neochelanops Beier, 1964 and Semeiochernes Beier, 1932 from the American region; Ceriochernes Beier, 1937 from Asia and South America; Eumecochernes Beier, 1932 from Hawaii; Nesochernes Beier, 1932 from New Zealand; and Austrochernes Beier, 1932, Marachernes Harvey, 1992, Paraustrochernes Beier, 1966, Satrapanus Harvey and Volschenk, 2007 and Troglochernes Beier, 1969 from Australia. Other chernetid genera may eventually be found to have this combination of characters, but their descriptions currently lack sufficient detail of one or both of these features.

Balgachernes differs from most of these genera in the placement of trichobothrium est which is much closer to esb than to et in Balgachernes (Figure 14), but approximately midway between them, or only slightly closer to esb, in Atherochernes (Beier 1954), Ceriochernes (Beier 1937), Cocinachernes (Hentschel and Muchmore 1989), Gigantochernes (Beier 1932; Vitali-di Castri 1972), Hesperochernes (e.g. Chamberlin 1924; Harvey and Wynne 2014; Muchmore 1974), Illinichernes (Benedict and Malcolm 1982; Hoff 1949), Marachernes bellus Harvey, 1992 (but not M. perup Harvey, 1992 or M. simulans Harvey, 1992) (Harvey 1992a), Maxchernes birabeni Feio, 1960 and $M$. plaumanni Beier, 1974 (but not M. iporangae Mahnert and Andrade, 1998) (Beier 1974; Feio 1960; Mahnert and Andrade 1998), Mirochernes (Hoff 1949), Neochelanops (Beier 1964a; Mahnert 1984), Nesochernes (Beier 1932), Paraustrochernes (Beier 1966a), Satrapanus (Harvey and Volschenk 2007), Semeiochernes (Beier 1932) and Troglochernes (Harvey and Volschenk 2007), or est closer to et than to esb in Eumecochernes (Beier 1932). It differs from Marachernes by the lack of a dentate prolateral mound on the male movable chelal finger (Harvey 1992a), and from Maxchernes by having isb situated closer to ist than to it, whereas isb is closer to it in Maxchernes (Beier 1974; Feio 1960; Mahnert and Andrade 1998). It differs from Austrochernes by the small, barely denticulate vestitural setae of the tergites, which are large and distinctly clavate in Austrochernes, and by the presence of denticles on the anterior face of all four rallar blades in Austrochernes (With 1905, plate VI, figure 2b), but only on the first two blades in Balgachernes (Figure 10). The most distinctive features, however, are the diastemeodentate chelal teeth and the gaping chelal fingers (Figures 14, 15).

\section{ETYMOLOGY}

The genus name refers to the common name 'balga' for Xanthorrhoea preissii, which is combined with the genus name Chernes (labourer, Greek). It is masculine in gender. 


\section{Balgachernes occultus sp. nov.}

\author{
urn:Isid:zoobank.org:act:06F81A74-595E-4978-87DD- \\ D4B312B7B0CC
}

Figures 3-28

\section{MATERIAL EXAMINED}

\section{Holotype}

Australia: Western Australia: + , Ashendon Road, east of Pickering Brook, 3202'13"S, 116 $11^{\prime} 35^{\prime \prime}$ E, 7 June 2001, ex Xanthorrhoea preissii, K.E.C. Brennan, M.L. Moir, R. Wittkuhn (WAM T143755).

\section{Paratypes}

Australia: Western Australia: 9 क, 9 क, 6 tritonymphs, same data as holotype (WAM T143732T143754, 143756); 4 ô, 3 ㅇ, Ashendon Road, $5.7 \mathrm{~km}$ E. of Pickering Brook, $32^{\circ} 02^{\prime} 11^{\prime \prime} \mathrm{S}, 116^{\circ} 11^{\prime} 36^{\prime \prime} \mathrm{E}, 18$ March 2018, in crown of X. preissii, C. Romero, M.S. Harvey (WAM T145155-T145161); 1 ô, same data except Ashendon Road, $6.3 \mathrm{~km}$ ESE. of Pickering Brook, except $32^{\circ} 02^{\prime} 55^{\prime \prime S}, 116^{\circ} 11^{\prime} 47^{\prime \prime} \mathrm{E}$ (WAM T145162); 1 ㅇ, 1 deutonymph, same data except Ashendon Road, 6.55 $\mathrm{km}$ ESE. of Pickering Brook, 32 03'30"S, 116 ${ }^{\circ} 11^{\prime} 44^{\prime \prime} \mathrm{E}$ (WAM T145163-145164); 2 ㅇ, same data except Ashendon Road, $7.7 \mathrm{~km}$ ESE. of Pickering Brook, $32^{\circ} 04^{\prime} 16^{\prime \prime} \mathrm{S}, 116^{\circ} 12^{\prime} 07^{\prime \prime E}$ (WAM T145165-145166); 2 ภे, same data except Ashendon Road, $8.1 \mathrm{~km}$ E. of Canning Mills, 3205'29"S, 116¹1'31"E (WAM T145167-145168); 1 ô, 2 ㅇ, same data except Ashendon Road, $7.3 \mathrm{~km}$ ESE. of Karragullen, $32^{\circ} 07^{\prime} 23^{\prime \prime} \mathrm{S}, 116^{\circ} 11^{\prime} 45^{\prime \prime} \mathrm{E}$ (WAM T145169-145171); 1 ภ, 1 क , same data except corner of Ashendon Road and Brookton Highway, $32^{\circ} 08^{\prime} 54 " \mathrm{~S}$, 116¹1'26"E (WAM T145172-145173).

\section{Other material}

Australia: Western Australia: 1 , Jarrahdale, Alcoa mine area, $32^{\circ} 16^{\prime} \mathrm{S}, 116^{\circ} 06^{\prime} \mathrm{E}$, August 2001 , beat sample, ex X. preissii, M.L. Moir (WAM T143730); 1 Oै, same data except May 2001 (WAM T143731); 4 +, John Forrest National Park [ca. $\left.31^{\circ} 53^{\prime} \mathrm{S}, 116^{\circ} 06^{\prime} \mathrm{E}\right]$, 9 January 1986, in crown of $X$. preissii, C. Reid, P.J. Gullan (WAM T145152-145154); 2 ô, 1 +, Scarp Road, $4.5 \mathrm{~km}$ SE. of North Dandalup, $32^{\circ} 32^{\prime} 28^{\prime \prime S}, 116^{\circ} 00^{\prime} 38^{\prime \prime} \mathrm{E}$, 1 April 2018, in crown of $X$. preissii, M.S. Harvey, M.E. Blosfelds (WAM T145214-145215); 2 ô, same data except Scarp Road, $4.5 \mathrm{~km}$ E. of North Dandalup, $32^{\circ} 31^{\prime} 25^{\prime \prime} \mathrm{S}, 16^{\circ} 01^{\prime} 09^{\prime \prime E}$ (WAM T145216-145217); 1 ○, 1 tritonymph, Scarp Road, 7.0 km NE. of North Dandalup, 32॰28'25"S，11601'26"E (WAM T145218-145219); 1 $\lambda, 1$ ㅇ, Kingsbury Drive, near North Dandalup Dam, $32^{\circ} 24^{\prime} 37 " \mathrm{~S}, 116^{\circ} 06^{\prime} 03 " \mathrm{E}$ (WAM T145220-145221); 1 , Stirling Range National Park, Bluff Knoll Road [ca. $\left.34^{\circ} 21^{\prime} \mathrm{S}, 118^{\circ} 13^{\prime} \mathrm{E}\right], 29$ December 1985 , at base of $X$. preissii heads, C. Reid, P.J. Gullan (WAM T145503).

\section{DIAGNOSIS}

As for genus.

\section{DESCRIPTION}

Adults

Colour: most cuticular surfaces dark red-brown; legs yellow-brown (Figures 3-7).

Chelicera: with 6 or occasionally 5 setae on hand and 1 subdistal seta on movable finger (Figures 9, 24); setae $e s, l s$ and is acuminate, $b s$, $b s$ " and $s b s$ dentate; with 2 dorsal lyrifissures and 1 ventral lyrifissure; galea stout with 5-6 ( $\widehat{\partial}$, + ) distal to subdistal rami (Figures 11, 12, 29); rallum composed of 4 blades, 2 anterior blades with fine serrations, 2 posterior blades smooth (Figure 10); serrula exterior with 15 (ठ), 14 () blades; lamina exterior present.

Pedipalp (Figure 13): all surfaces granulate, except for smooth chelal fingers; all segments robust, trochanter

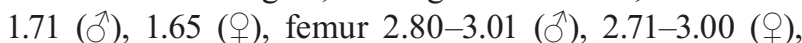
patella 2.01-2.62 (ð), 2.28-2.41 (), chela (with pedicel) 2.73-3.24 (ð), 2.80-3.19 (†), chela (without pedicel) 2.53-3.06 (ð), 2.63-2.95 (+), hand (without pedicel) 1.24-1.54 (ð), $0.92-1.07(+) \times$ longer than broad, movable finger $0.89-1.03($ ( $), 1.38-1.51($ ( $) \times$ longer than hand (without pedicel). Fixed chelal finger with 8 trichobothria, movable chelal finger with 4 trichobothria (Figure 14): $e b$ and $e s b$ situated basally; est situated closer to $e s b$ than to $e t ; i b$ and ist subbasally; it situated midway between et and est; isb situated closer to $i b$ and $i s t$ than to $i t ; t$ situated subdistally; st situated closer to $s b$ than to $t$; and $s b$ situated much closer to $b$ than to st. Fixed and movable fingers without pseudotactile setae (Figure 14). Venom apparatus only present in movable chelal finger, venom duct long, terminating in nodus ramosus between st and $t$. Fingers slightly gaping (Figures 14, 15). Chelal teeth diastemodentate, slightly retrorse (Figure 15), basal teeth more rounded and juxtadentate; fixed finger with $24(\hat{\partial}$, ) $)$ teeth, plus $1(\delta,+9)$ retrolateral accessory tooth situated subdistally between teeth 6 and $7(\widehat{\jmath})$, or 7 and $8(+)$, and $8(\AA)$, or 7 (9) prolateral accessory teeth; movable finger with $25(\hat{\sigma},+)$ teeth, with $3(\hat{\jmath}), 4(9)$ retrolateral and 8 $($ đ), 6 (†) prolateral accessory teeth; sense spots: fixed chelal finger with $6\left(\circlearrowleft^{\Uparrow}\right), 8(+)$ retrolateral and $5\left({ }^{\Uparrow}\right)$, 13 () prolateral; movable chelal finger with $3(\hat{\sigma},+$ ) retrolateral and $8\left(\delta^{\Uparrow}\right), 6(+)$ prolateral.

Carapace (Figure 8): evenly granulate; 0.97-1.12 (ठ), 0.94-1.13 (†) $\times$ longer than broad; with 1 pair of small, very faint eye-spots; with $38(\hat{\jmath},+)$ setae in anterior zone, including 4 near anterior margin, $29\left(\delta^{\text {ㄱ) }}\right.$,

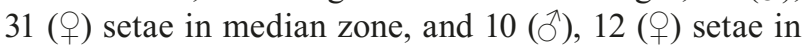
posterior zone; with 2 distinct furrows, posterior furrow situated closer to posterior margin of carapace than to anterior furrow; posterior margin straight.

Coxal region: maxillae granulate; dorso-lateral region of coxae I-IV granulate, other surfaces smooth; manducatory process somewhat pointed, with 2-3 apical to sub-apical acuminate setae, 1 small sub-oral seta, and $24($ Љ), 19 (ㅇ) additional setae; median maxillary lyrifissure rounded and situated submedially; posterior maxillary lyrifissure rounded. Chaetotaxy of coxae IIV: $\hat{\jmath}, 10: 12: 15: 37$; ㅇ, 11: 12: 19: ca. 45. 

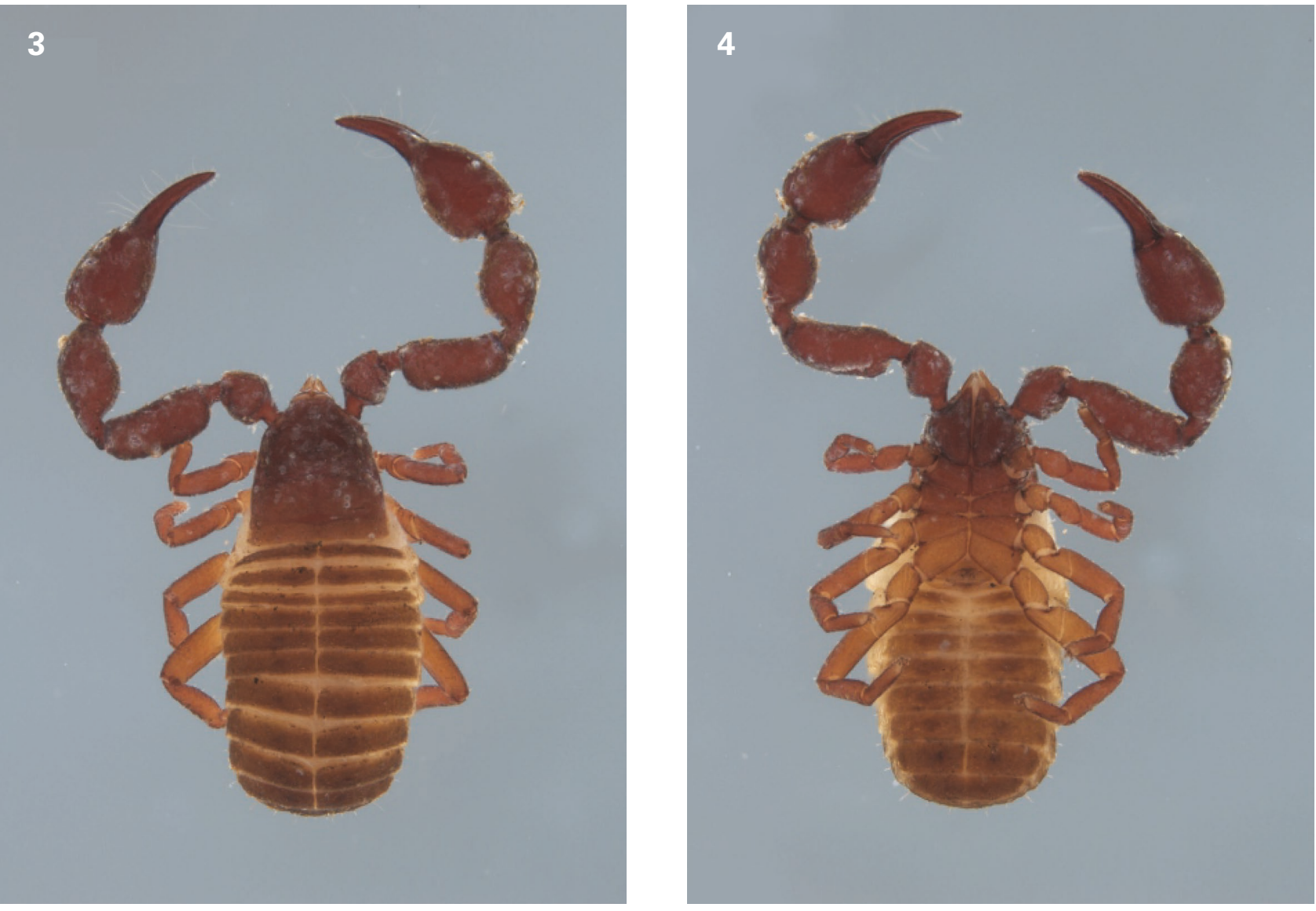

5

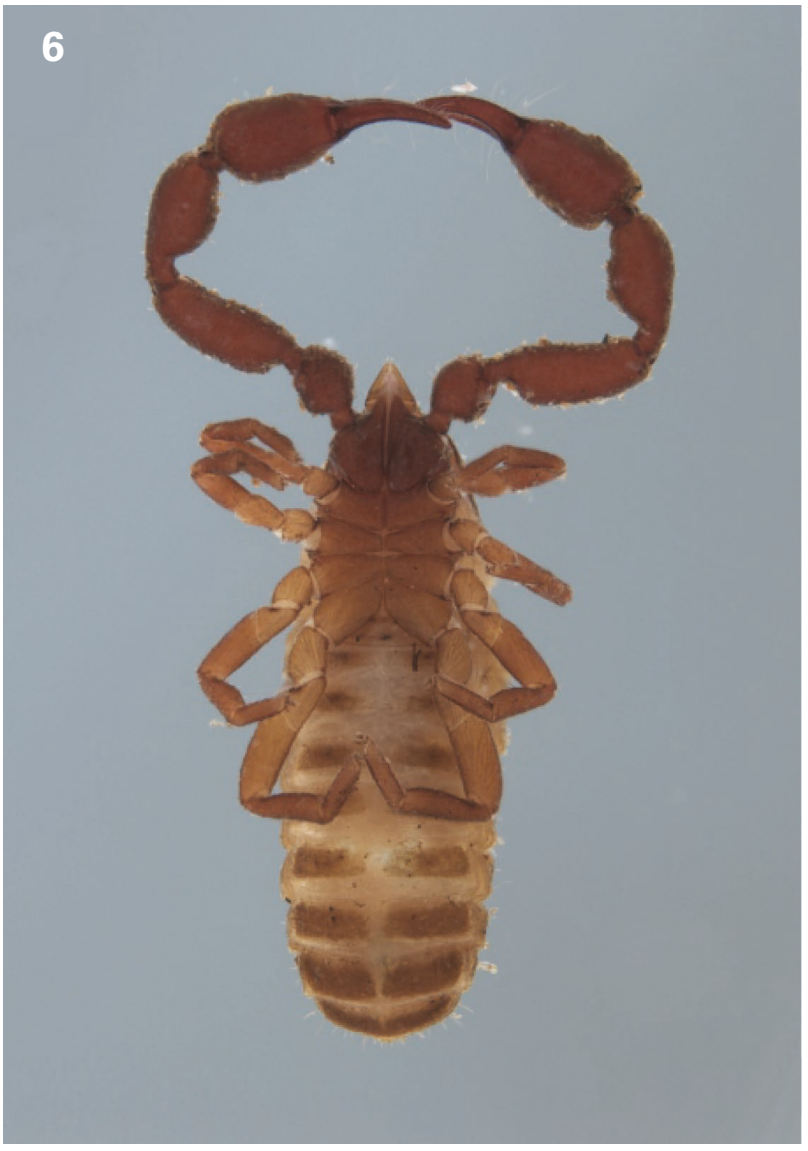

FIGURES 3-6

Balgachernes occultus sp. nov.: 3, 4, male paratype (WAM T143751): 3, dorsal view; 4, ventral view; 5-6, female paratype (WAM T143754): 5, dorsal view; 6, ventral view. 


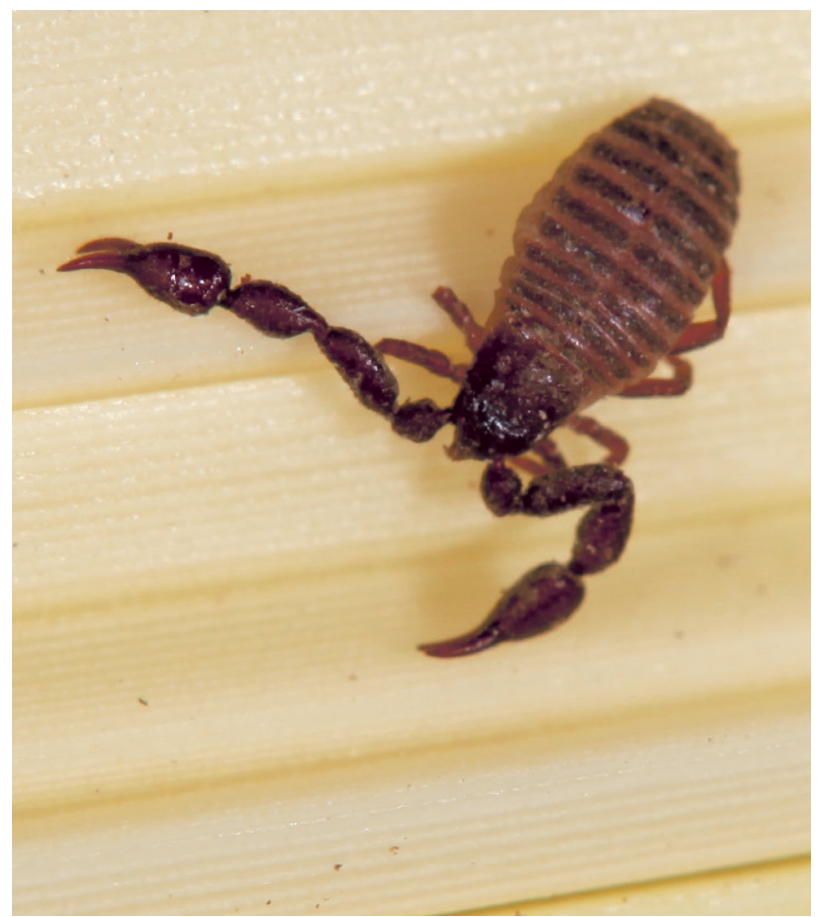

FIGURE 7

Balgachernes occultus sp. nov., female photographed alive among newly developing leaves within the head of a balga (Xanthorrhoea preissii).

Legs: junction between femora and patellae I and II strongly oblique to long axis (Figure 18); junction between femora and patellae III and IV very angulate; femora III and IV much smaller than patellae III and IV; femur + patella of leg IV $3.49\left(\oslash^{\Uparrow}\right), 3.55(+) \times$ longer than broad (Figure 19); patella and tibia III and IV without pseudotactile setae; tarsi III and IV without tactile seta (Figures 19, 27); tarsi with single raised slit sensillum; subterminal tarsal setae arcuate and acute (Figure 27); claws not modified (Figure 27); arolium slightly shorter than claws (Figure 28).

Abdomen: tergites I-X and sternites IV-X with medial suture line (Figures 3-6). Tergal chaetotaxy: ๙ૈ, 13: 19: 13: 17: 20: 21: 20: 17: 16:14: 10: 2; + , 13: 14: 13: 16: 17: 18: 16: 17: 17: 14: 12: 2; setae short and dentate. Sternal chaetotaxy: ô, 44: (1) 18 [3 + 3] (1): (1) 6 (1): 15: 16: 16: 16: 15: 15: 10: 2; ㅇ, 29: (1) 8 (1): (1) 9 (1): 11: 16: 16: 15: 15: 15: 10 (including 4 longer setae): 2 . Sternite II of $\delta$ with setae arranged in inverted-U over median third; sternite III with setae widely scattered (Figure 20); of $q$ with setae arranged in inverted- $U$, without setae on posterior margin; sternite III of $q$ with setae on posterior margin (Figure 21). Pleural membrane irregularly longitudinally striate; without setae.

Genitalia: male of typical chernetid morphology; female with paired spermathecae with bulbous receptacula (Figure 22).

Dimensions $(\mathrm{mm})$ : paratype male (WAM T143751), followed by 9 other paratype males (when measured) in parentheses: Body length 2.74 (2.83-3.58). Pedipalps: trochanter $0.555 / 0.325$, femur $0.930 / 0.330(0.860-$ $1.010 / 0.295-0.345)$, patella $0.800 / 0.385$ (0.765$0.890 / 0.325-0.430$ ), chela (with pedicel) $1.405 / 0.515$ (1.330-1.535/0.41-0.535), chela (without pedicel) 1.305 (1.250-1.410), hand (without pedicel) length 0.640 (0.620-0.780), movable finger length 0.660 (0.635$0.705)$. Chelicera $0.305 / 0.16$, movable finger length 0.21 . Carapace 0.990/0.920 (0.965-1.075/0.870-1.040); eye diameter 0.065 . Leg I: femur $0.290 / 0.185$, patella $0.470 / 0.180$, tibia $0.385 / 0.185$, tarsus $0.345 / 0.090$. Leg IV: femur + patella $0.820 / 0.235$, tibia $0.610 / 0.150$, tarsus $0.415 / 0.115$.

Dimensions (mm): holotype female (WAM T143755), followed by 10 other paratype females (when measured) in parentheses: Body length 3.76 (2.11-3.56). Pedipalps: trochanter $0.560 / 0.340$, femur $0.910 / 0.325(0.80-$ $0.945 / 0.295-0.330)$, patella $0.830 / 0.355(0.740-$ $0.850 / 0.310-0.370$ ), chela (with pedicel) $1.395 / 0.470$ (1.220-1.415/0.420-0.505), chela (without pedicel) 1.320 (1.130-1.350), hand (without pedicel) length 0.655 (0.580-0.695), movable finger length 0.670 (0.5700.680 ). Chelicera $0.305 / 0.160$, movable finger length 0.235. Carapace 1.070/1.030 (0.945-1.025/0.910-1.030); eye diameter 0.065 . Leg I: femur $0.320 / 0.105$, patella $0.475 / 0.175$, tibia $0.380 / 0.130$, tarsus $0.215 / 0.095$. Leg IV: femur + patella $0.835 / 0.235$, tibia $0.580 / 0.145$, tarsus $0.385 / 0.110$.

\section{Tritonymphs}

Colour: most cuticular surfaces pale red-brown; legs yellow-brown.

Chelicera: with 5 setae on hand and 1 subdistal seta on movable finger; setae $e s, l s$ and $i s$ acuminate, $b s$ and $s b s$ dentate; galea with 5 distal to subdistal rami; rallum of 4 blades, 2 anterior blades with fine serrations, 2 posterior blades smooth.

Pedipalp: trochanter 1.76, femur 2.44, patella 2.18, chela (with pedicel) 3.35, chela (without pedicel) 3.13, hand (without pedicel) $1.56 \times$ longer than broad, movable finger $1.00 \times$ longer than hand (without pedicel). Fixed chelal finger with 7 trichobothria, movable chelal finger with 3 trichobothria (Figure 16): $e b$ and $e s b$ situated basally; est situated closer to $e s b$ than to et; $i b$ and ist subbasally; it situated midway between et and est; st situated midway between $b$ and $t$. Venom duct long, terminating in nodus ramosus near $t$. Fingers slightly gaping (Figure 16). Chelal teeth diastemodentate; fixed finger with 25 teeth, plus 1 retrolateral accessory tooth situated subdistally, no prolateral accessory teeth; movable finger with 26 teeth, without accessory teeth; sense spots: fixed chelal finger with 3 retrolateral and 0 prolateral; movable chelal finger with none.

Carapace: evenly granulate; $1.45 \times$ longer than broad; with 1 pair of small, very faint eye-spots; with 28 setae in anterior zone, including 4 near anterior margin, 12 setae in median zone, and 8 setae in posterior zone; with 2 furrows, anterior furrow rather faint, posterior furrow 

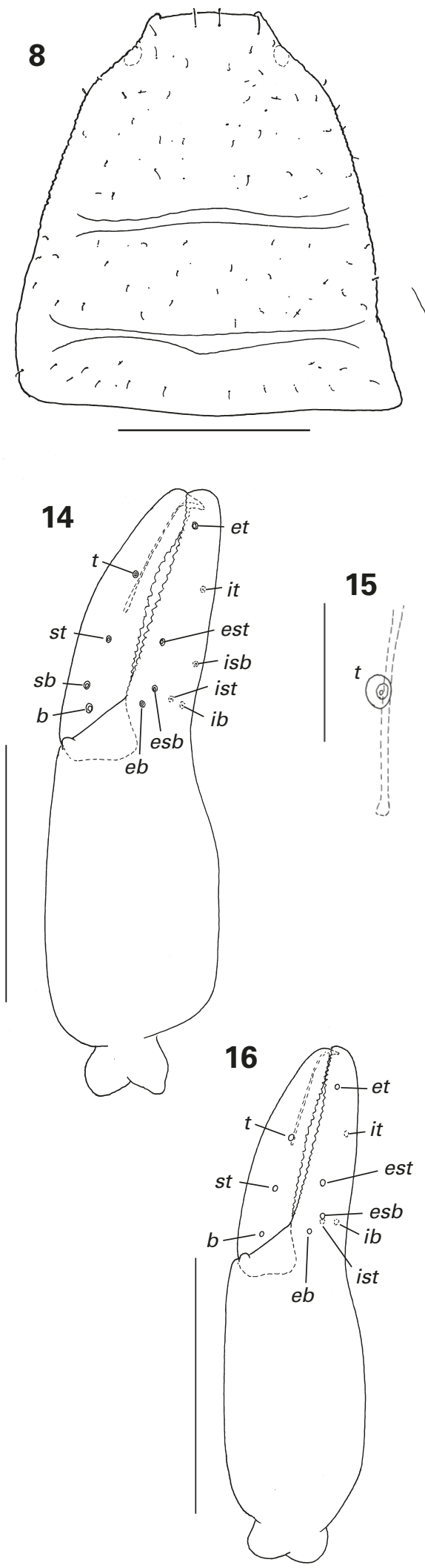

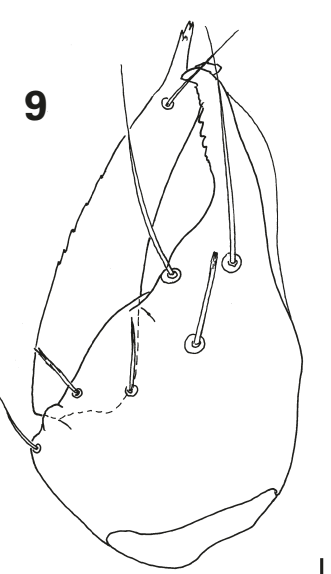

10

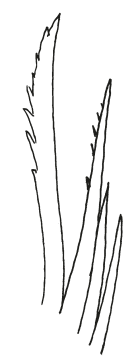

11

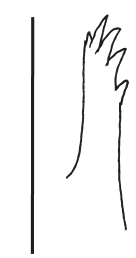

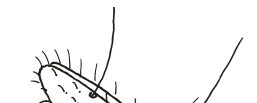

13
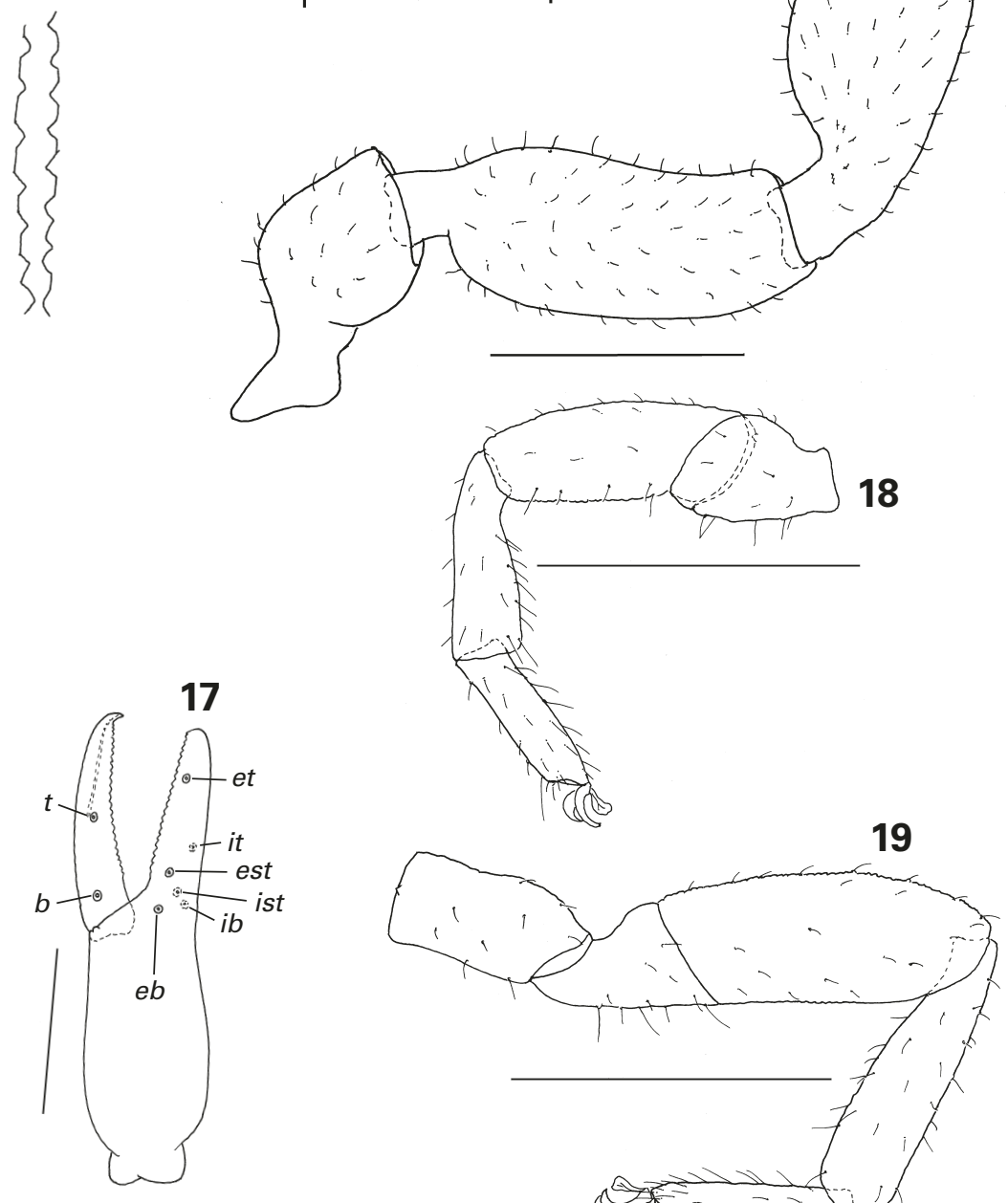

19

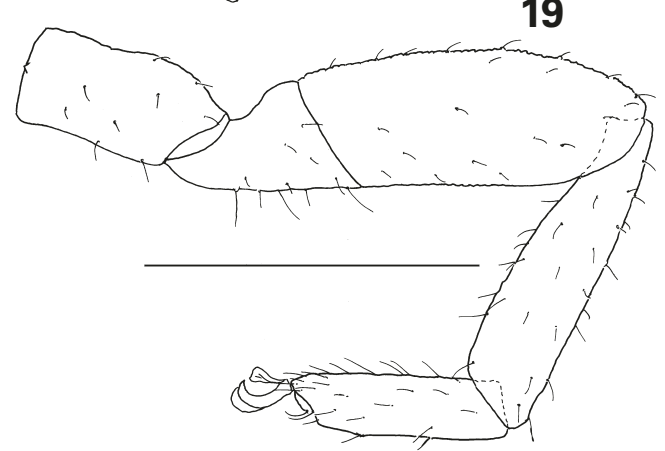

FIGURES 8-19 Balgachernes occultus sp. nov., female holotype (WAM T143755), unless stated otherwise: 8, carapace, dorsal view; 9, left chelicera, dorsal view; 10, left rallum, lateral view; 11, left galea, lateral view; 12, left galea, lateral view, male paratype (WAM T143751); 13, right pedipalp, dorsal view; 14, left chela, lateral view, setae omitted; 15, left chelal teeth, lateral view; 16, left chela, lateral view, setae omitted, tritonymph paratype (WAM T143746); 17, left chela, lateral view, setae omitted, deutonymph paratype (WAMT145164); 18, left leg I, lateral view; 19, left leg IV, lateral view. Scale lines $=0.5 \mathrm{~mm}$ (Figures 8, 13, 14, 16-19), $0.1 \mathrm{~mm}$ (Figures 9, 15), $0.05 \mathrm{~mm}$ (Figures 10-12). 

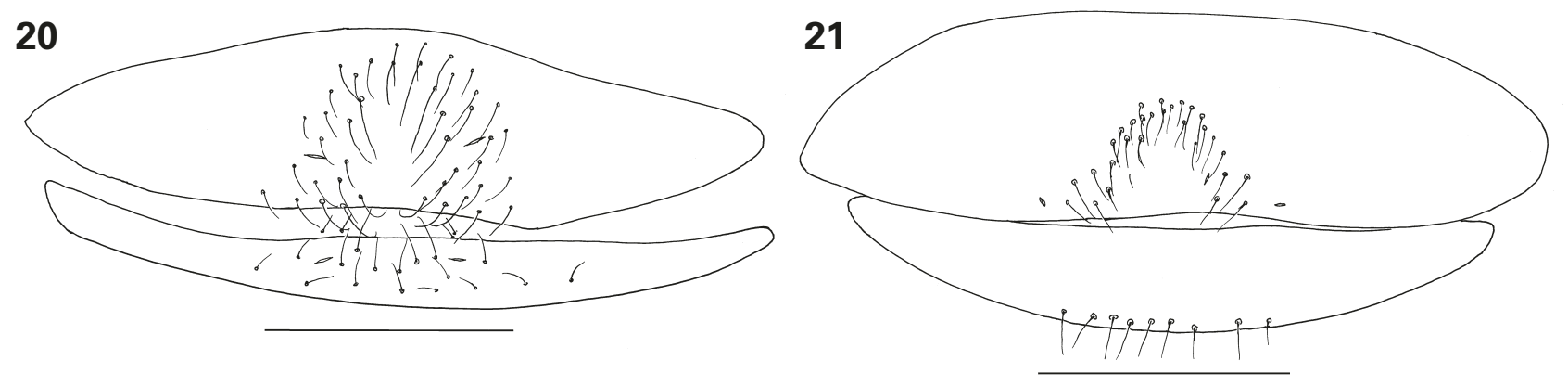

22

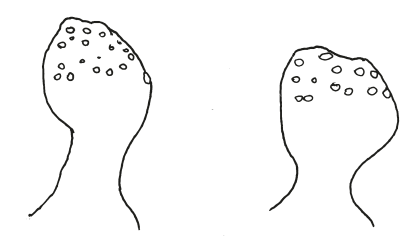

FIGURES 20-22 Balgachernes occultus sp. nov.: 20, genital sternites, ventral view, male paratype (WAM T143751); 21-22, female holotype (WAM T143755): 21, genital sternites, ventral view; 22, spermathecae, ventral view. Scale lines $=0.2 \mathrm{~mm}$ (Figures 20, 21), $0.1 \mathrm{~mm}$ (Figure 22).

situated closer to posterior margin of carapace than to anterior furrow; posterior margin straight.

Coxal region: maxillae with 3 apical to sub-apical acuminate setae, 1 small sub-oral seta, and 19 additional setae. Chaetotaxy of coxae I-IV: 7: 8: 8: 15.

Legs: very similar to adults.

Abdomen: tergites I-X and sternites II-X with median suture line. Tergal chaetotaxy: 10: 12: 10: 12: 14: 13: 16: 13: 12: 9: 12: 2. Sternal chaetotaxy: 6: (1) 5 (1): (2) 5 (2): 12: 12: 14: 14: 15: 11: 9: 2 .

Dimensions (mm): paratype (WAM T143746): Body length 3.01. Pedipalps: trochanter 0.395/0.225, femur $0.610 / 0.250$, patella $0.555 / 0.255$, chela (with pedicel) $1.040 / 0.310$, chela (without pedicel) 0.970 , hand (without pedicel) length 0.485 , movable finger length 0.485 . Carapace 0.805/0.770.

\section{Deutonymphs}

Colour: most cuticular surfaces pale red-brown; legs yellow-brown.

Chelicera: with 5 setae on hand and 1 subdistal seta on movable finger; setae $e s, l s$ and is acuminate, $b s$ and $s b s$ dentate; galea with 3 distal rami; rallum of 4 blades, 2 anterior blades with fine serrations, 2 posterior blades smooth.

Pedipalp: trochanter 1.90, femur 2.34, patella 2.09, chela (with pedicel) 3.33, chela (without pedicel) 3.12 , hand (without pedicel) $1.51 \times$ longer than broad, movable finger $1.06 \times$ longer than hand (without pedicel). Fixed chelal finger with 6 trichobothria, movable chelal finger with 2 trichobothria (Figure 17): eb situated basally; est situated closer to $e s b$ than to $e t ; i b$ and ist subbasally; it closer to est than to est; $t$ situated slightly closer to $t$ than to tip of finger. Venom duct long, terminating in nodus ramosus near $t$. Fingers slightly gaping (Figure 17\#). Chelal teeth slightly diastemodentate; fixed finger with 21 teeth, without accessory teeth; movable finger with 24 teeth, without accessory teeth or sense spots.

Carapace: evenly granulate; $0.97 \times$ longer than broad; with 1 pair of small, very faint eye-spots; with 26 setae in anterior zone, including 4 near anterior margin, 10 setae in median zone, and 6 setae in posterior zone; with 2 shallow furrows, posterior furrow situated closer to posterior margin of carapace than to anterior furrow; posterior margin straight.

Coxal region: maxillae with 2 apical to sub-apical acuminate setae, 1 small sub-oral seta, and 9 additional setae. Chaetotaxy of coxae I-IV: 5: 6: 7: 8 .

Legs: very similar to adults.

Abdomen: tergites I-X and sternites II-X with median suture line. Tergal chaetotaxy: 6: 10: 8: 10: 9: 9: 10: 10: 10: 8: 8: 2. Sternal chaetotaxy: 0: (1) 4 (1): (2) 4 (2): 10 : 10: 10: 10: 10: 10: 6: 2 .

Dimensions ( $\mathrm{mm}$ ): paratype (WAM T145164): Body length 2.10. Pedipalps: trochanter $0.285 / 0.150$, femur $0.410 / 0.175$, patella $0.365 / 0.175$, chela (with pedicel) $0.715 / 0.215$, chela (without pedicel) 0.670 , hand (without pedicel) length 0.325 , movable finger length 0.345 . Carapace 0.545/0.560.

\section{REMARKS}

Despite considerable collecting of pseudoscorpions in south-western Australia, specimens of Balgachernes occultus have only been recorded from grass trees 

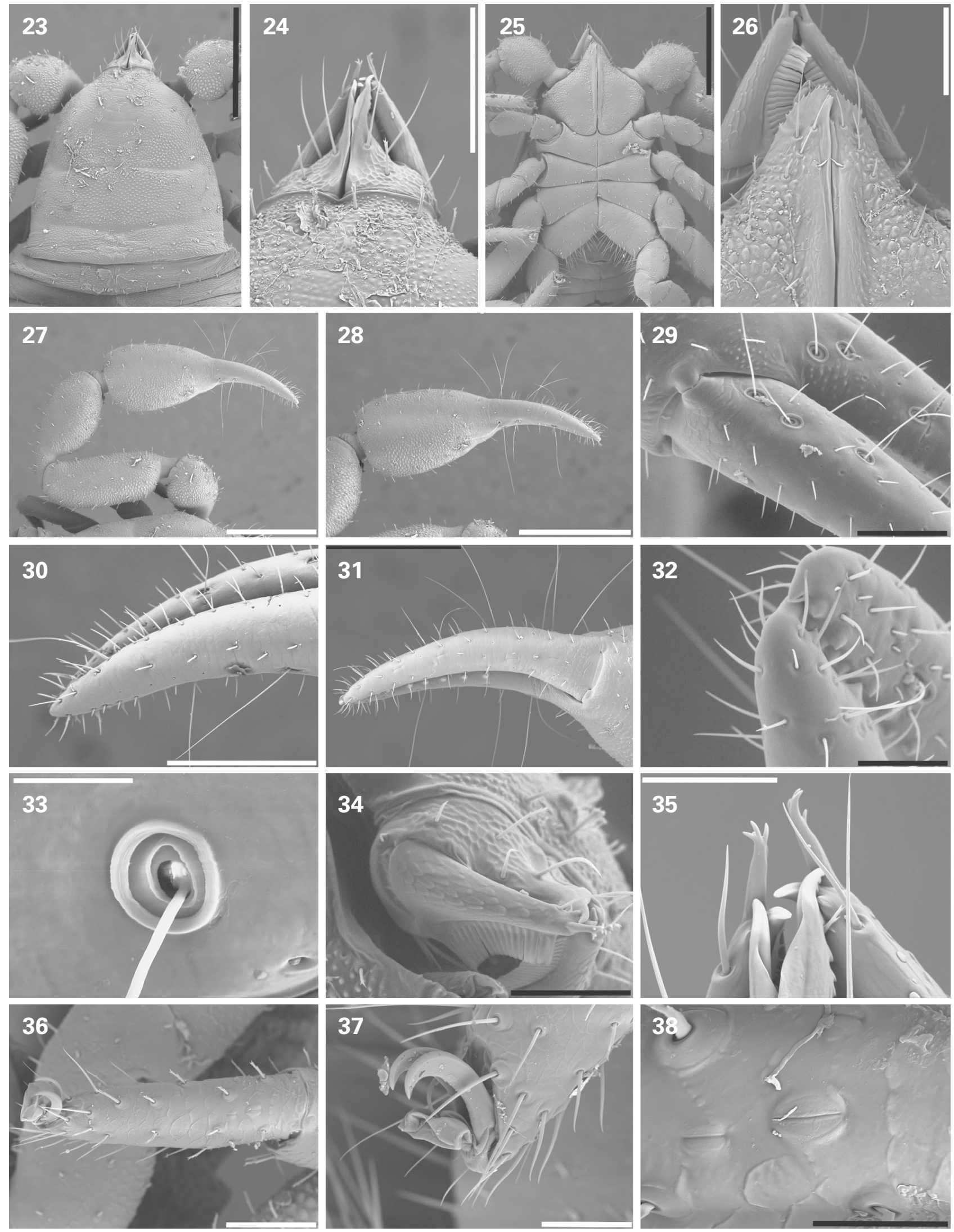

FIGURES 23-38 Balgachernes occultus sp. nov., female, scanning electron micrographs: 23, cephalothorax, dorsal; 24, chelicera, dorsal; 25, cephalothorax, ventral; 26, manducatory process, ventral; 27, left pedipalp, dorsal; 28, left chela, dorsal; 29, right chelal fingers; 30, tip of right chelal fingers, dorsal; 31, left chelal fingers, ventral; 32 , tip of left chelal fingers, lateral; 33, trichobothrium ib; 34, right chelicera; 35, tips of chelicerae, dorsal; 36, right tarsus II; 37, tip of right tarsus III; 38, lyrifissures of right tarsus II. Scale lines $=500 \mu \mathrm{m}$ (Figures 23, 25, 27, 28), $300 \mu \mathrm{m}$ (Figure 31), $200 \mu \mathrm{m}$ (Figures 24, 30), $100 \mu \mathrm{m}$ (Figures 26, 29, 34, 36 ), $50 \mu \mathrm{m}$ (Figures 32, 35, 37), 30 $\mu \mathrm{m}$ (Figure 38), $20 \mu \mathrm{m}$ (Figure 33). 
(X. preissii) in the Darling Range and Stirling Range National Park of south-western Australia (Brennan et al. 2011; this paper, Figure 29). In a study of the effects of fire on invertebrates in grass trees, Brennan et al. (2011) found B. occultus in every unburnt grass tree in their study site and found it to be more abundant in the dead skirts than the crowns. Pseudoscorpions did not appear to survive the fires as no individuals were found on burnt grass trees (Brennan et al. 2011, Appendix 3). Specimens were found in about a third of the heads of grass trees inspected along a $12 \mathrm{~km}$ stretch of Ashendon Road on 18 March 2018. They were detected by parting the new leaves at the head of the tree (Figure 7) but they moved rapidly down into the head of the tree when exposed. The dead leaves that form the skirt of the grass trees were not sampled. A survey of balga trees on 1 April 2018 at five sites in the Dwellingup region $\left(32^{\circ} 44^{\prime} 42^{\prime \prime} \mathrm{S}\right.$, $116^{\circ} 00^{\prime} 05^{\prime \prime E}$; $32^{\circ} 42^{\prime} 28^{\prime \prime S}$, $116^{\circ} 03^{\prime} 38^{\prime \prime E}$; 32 3241'08"S, $116^{\circ} 02^{\prime} 19^{\prime \prime E} ; 32^{\circ} 37^{\prime} 46^{\prime \prime S}, 115^{\circ} 58^{\prime} 28^{\prime \prime E} ; 32^{\circ} 37^{\prime} 01^{\prime \prime S}$, $\left.115^{\circ} 55^{\prime} 33^{\prime \prime} \mathrm{E}\right)$ failed to locate any pseudoscorpions, whereas searching the heads of balga only $10 \mathrm{~km}$ to the north on Scarp Road quickly detected the presence of B. occultus. Continuing north for about $25 \mathrm{~km}$, the only forest sites that lacked B. occultus were those that had been burnt during the last few years, as evidenced by blackened tree bark and reduced ground leaf litter.

Although other habitats directly adjacent to the grass trees were not searched for pseudoscorpions during these surveys, the author has collected and examined hundreds of pseudoscorpions from other habitats such as tree bark, leaf litter and under stones in the Darling and Stirling Ranges, and Balgachernes has not been detected. Therefore, it seems reasonable to assume that B. occultus is a balga specialist.

There are no available data on how the pseudoscorpions recolonise balga after fires, but the gaping chelal fingers found in adults, tritonymphs, deutonymphs (Figures 14-17), and possibly protonymphs, may indicate a modification for attachment to other arthropods by providing space between the fingers to grip onto the legs of insects. This mode of transport, known as phoresy (Muchmore 1971), is common among some pseudoscorpion taxa, especially in chernetids and other members of the Cheliferoidea (e.g. Aguiar and Bührnheim 1998; Gärdenfors and Wilander 1995; Muchmore 1971; Pfeiler et al. 2009; Poinar et al. 1998; Zeh and Zeh 1992a, b).

It is extremely unlikely that $B$. occultus is the sole species of the genus, with some 28 recognised species of Xanthorrhoea from eastern, south-western and central Australia (see Flora of Australia online, http:// www.anbg.gov.au/abrs/online-resources/flora/redirect. jsp; accessed 2 April 2018) seemingly providing ample habitat for pseudoscorpions.

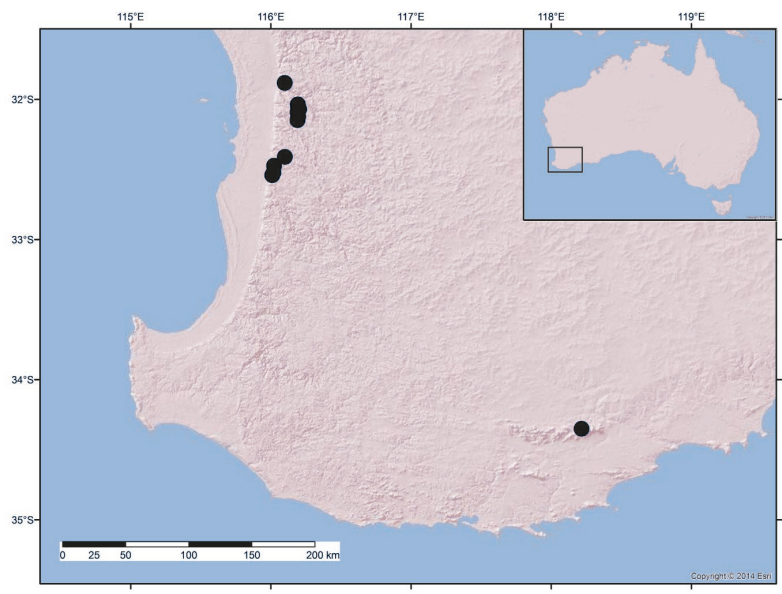

FIGURE 39

Map of south-western Australia showing recorded distribution of Balgachernes occultus sp. nov.

\section{ETYMOLOGY}

The name refers to this species preference for living among balga leaves [occultus, Latin, cover, conceal; see Brown (1956)].

\section{Genus Austrochernes Beier, 1932}

urn:Isid:zoobank.org:act:E30B0461-E700-42CB-B8154F332089968A

Austrochernes Beier 1932: 171.

Troglochernes Beier 1969: 185. Syn. nov.

\section{TYPE SPECIES}

Austrochernes: Chelifer australiensis With, 1905, by original designation.

Troglochernes: Troglochernes imitans Beier, 1969, by original designation.

\section{DIAGNOSIS}

Austrochernes differs from all other chernetid genera by the following combination of characters (from Harvey and Volschenk 2007): flagellum with 4 blades, or possibly 3 blades in one species; spermathecae with 2 thickened and slightly curved tubes fused basally; legs III and IV without tactile setae (Figure 47); carapace unicolored and with two transverse furrows (Figures $42,45)$; chelal fingers not gaping or slightly gaping (e.g. Figure 43); eyes or eyespots absent (Figure 42); vestitural setae generally small, dentate and clavate (Figures 40, 42).

\section{REMARKS}

Beier (1932) described Austrochernes from the Australasian region and included four species: $A$. novazealandica (Beier, 1932) from New Zealand, and A. australiensis (With, 1905), A. ramosus (Koch and 
Keyserling, 1885) and A. silvestrii (Beier, 1930) from Australia. While it appears that he relied on his firsthand knowledge of $A$. novazealandica and $A$. silvestrii to form the generic diagnosis, it seems that he did not have access to the type specimens of $A$. australiensis and $A$. ramosus as his descriptions only included data that were taken from the original descriptions by With (1905) and Koch and Keyserling (1885), respectively. Curiously, he designated $A$. australiensis as the type species, despite many differences between the four species. Indeed, they are currently included in four separate genera, with $A$. novazealandica in Heterochernes Beier, 1966, A. australiensis in Austrochernes, A. ramosus in Haplochernes Beier, 1932, and A. silvestrii as a junior synonym of Conicochernes brevispinosus (Koch and Keyserling, 1885) (Beier 1948b, 1966a, b). The diagnosis provided by Beier (1932) seems to be based more on $A$. novazealandica than on the type species, as he specifically mentions the presence of a tactile seta on tarsus IV which is present in A. novazealandica but absent in A. australiensis. Beier (1966b) later recognised the significant morphological differences between these two species, and transferred $A$. novazealandica to his new genus Heterochernes, leaving A. australiensis as the only species of Austrochernes. Harvey and Volschenk (2007) erroneously suggested that a tactile seta was present on tarsus IV of Austrochernes, mistakenly using the diagnosis provided by Beier (1932). This feature was then used to segregate Troglochernes from Austrochernes. Examination of the two male syntypes of $A$. australiensis shows that a tactile seta is indeed absent from the posterior legs, as originally reported by With (1905), and therefore Troglochernes cannot be differentiated from Austrochernes by this criterion. Austrochernes australiensis has all of the other characteristic features of Troglochernes, including a rallum with four blades, carapace unicoloured and with two transverse furrows, eyes or eyespots absent, and vestitural setae generally small, dentate and clavate. The only feature that could not be verified is the morphology of the spermathecae, which in Troglochernes consist of two thickened and slightly curved tubes fused basally (Harvey and Volschenk 2007). Nevertheless, there appears to be no compelling reason to keep the two genera as separate entities, and therefore Troglochernes is synonymised with Austrochernes, and all six species of Troglochernes are transferred to Austrochernes, as follows:

Austrochernes cruciatus (Volschenk, 2007), comb. nov., originally described in Troglochernes (Harvey and Volschenk 2007).

Austrochernes dewae (Beier, 1967), comb. nov., originally described in Sundochernes (Beier 1967).

Austrochernes guanophilus (Beier, 1967), comb. nov., originally described in Sundochernes (Beier 1967).

Austrochernes imitans (Beier, 1969), comb. nov., originally described in Troglochernes (Beier 1969).

Austrochernes novaeguineae (Beier, 1965), comb. nov., originally described in Sundochernes (Beier 1965).
Austrochernes omorgus (Harvey and Volschenk, 2007), comb. nov., originally described in Troglochernes (Harvey and Volschenk (2007).

Harvey and Volschenk (2007) found that species of Troglochernes were associated with guano deposits in cave environments (A. cruciatus, A. dewae, $A$. guanophilus and $A$. imitans) or with flying insects (A. omorgus). However, the habitat preferences of $A$. australiensis and $A$. novaeguineae were not stated in the original descriptions (Beier 1965; With 1905).

\section{Austrochernes australiensis (With, 1905)}

urn:Isid:zoobank.org:act:FF371C16-56D3-42F5-A545248BB8193A21

\section{Figures $40-48$}

Chelifer australiensis With 1905: 101-104, plate 6 figures $2 \mathrm{a}-\mathrm{g}$.

Austrochernes australiensis (With): Beier 1932: 171; Judson 1997: 9.

Not Chelifer (Trachychernes) australiensis (With): Ellingsen 1910: 373 [misidentification for Heterochernes novazealandiae (Beier)].

\section{MATERIAL EXAMINED}

\section{Syntypes}

Australia: Queensland: $2 \hat{\jmath}$, without further locality data or date, W.W. Froggart [sic, W.W. Froggatt] (BMNH 1893.12.17.-). See Remarks.

\section{DIAGNOSIS}

Austrochernes australiensis differs from A. imitans by the robust pedipalps (slender in $A$. imitans), and from all other species by its substantially larger size, e.g. chela (with pedicel) $2.33-2.44(\widehat{)}) \mathrm{mm}$ in $A$. australiensis and 1.00-1.34 (ठ), 1.05-1.61 (ㅇ) $\mathrm{mm}$ long in A. cruciatus, A. dewae, A. guanophilus, A. novaeguineae and $A$. ormogus.

\section{DESCRIPTION}

\section{Adult males}

Colour: most cuticular surfaces deep red-brown (Figures 40-42); legs yellow-brown.

Chelicera: with 7 setae on hand and 1 subdistal seta on movable finger; setae $b s^{\prime}, b s^{\prime \prime}, b s^{\prime \prime}$, and $s b s$ dentate, and $e s, l s$ and is acuminate; with 2 dorsal lyrifissures and 1 ventral lyrifissure; galea slender with 5-6 distal to subdistal rami (Figure 48); rallum of 4 blades, each with fine serrations; serrula exterior with 29 blades; lamina exterior present.

Pedipalp (Figure 44): pedipalpal surfaces finely granulate; patella with several subbasal lyrifissures; all segments robust, trochanter 1.40-1.55, femur 2.37, 

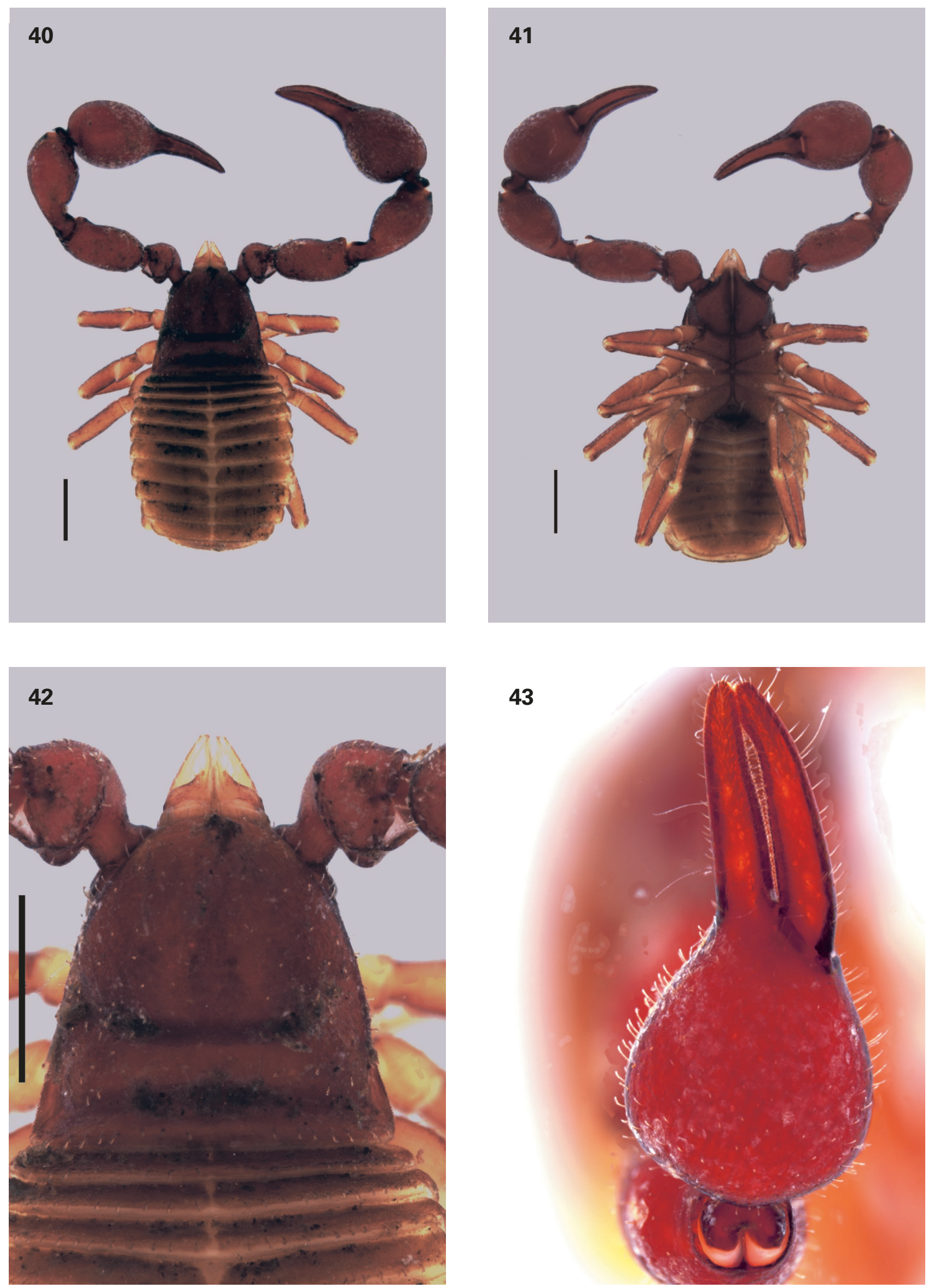

FIGURES 40-43 Austrochernes australiensis (With, 1905), male syntype (BMNH 1893.12.17): 40, dorsal view; 41, ventral view; 42, cephalothorax, dorsal view; 44, right chela, lateral. Scale lines $=0.5 \mathrm{~mm}$. 
patella 2.06-2.08, chela (with pedicel) 2.65-2.71, chela (without pedicel) 2.42-2.51, hand (without pedicel) 1.16 $\times$ longer than broad, movable finger $1.13-1.18 \times$ longer than hand (without pedicel). Fixed chelal finger with 8 trichobothria, movable chelal finger with 4 trichobothria (Figure 46): $e b$ and $e s b$ situated basally; est situated midway between $e s b$ and $e t ; i b$ and ist subbasally; it situated closer to et than to est; isb situated closer to it than to $i b$ and $i s t ; t$ situated closer to fingertip than $s t$; $s t$ situated closer to $t$ than to $s b$; and $s b$ situated much closer to $b$ than to st. Fixed and movable fingers without pseudotactile setae. Venom apparatus only present in movable chelal finger, venom duct long, terminating in nodus ramosus between st and $t$, but slightly closer to $s t$ (Figure 46). Finger slightly gaping near distal end
(Figure 46). Chelal teeth small and juxtadentate; fixed finger with 46 teeth, plus 8 retrolateral and 7 prolateral accessory teeth; movable finger with 50 teeth, plus 11 retrolateral and 5 prolateral accessory teeth; with sense spots on both fingers.

Carapace (Figures 42, 45): evenly granulate; 0.85$0.93 \times$ longer than broad; without eyes or eye-spots; with ca. 80 setae in anterior zone, including 6 near anterior margin, 55 setae in median zone, and 21 setae in posterior zone; with 2 distinct furrows, posterior furrow situated closer to posterior margin of carapace than to anterior furrow; posterior margin straight.

Coxal region: maxillae and coxae I-IV smooth; manducatory process somewhat pointed, with 3 apical to sub-apical acuminate setae, 1 small sub-oral seta,

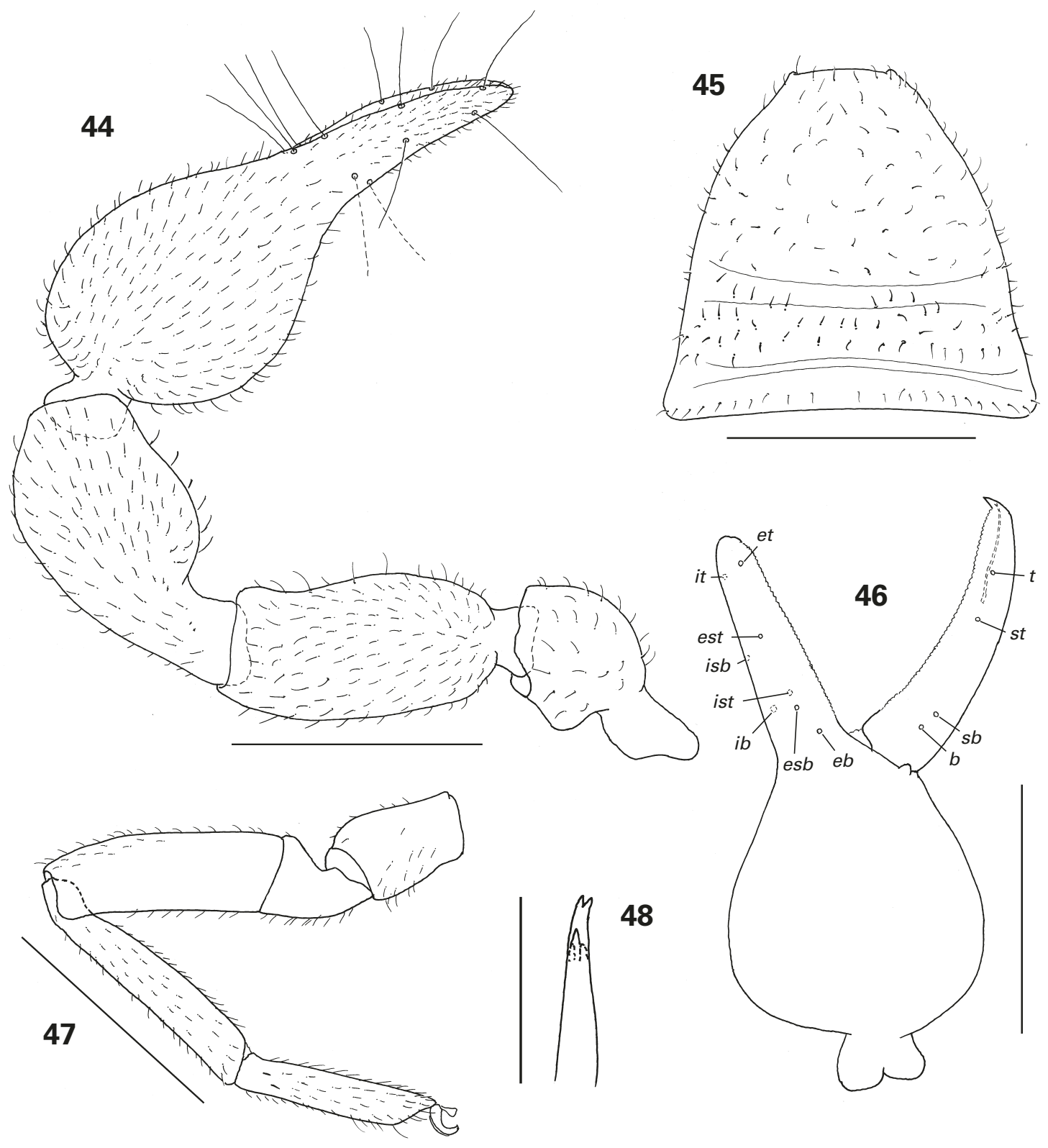

FIGURES 44-48 Austrochernes australiensis (With, 1905), male syntype (BMNH 1893.12.17): 44, left pedipalp, dorsal view; 45, carapace, dorsal view; 46, right chela, lateral view, setae omitted; 47, left leg IV, lateral view; 48, left galea, lateral view. Scale lines $=1.0 \mathrm{~mm}$ (Figures 44-47), $0.05 \mathrm{~mm}$ (Figure 48). 
and ca. 70 additional setae; median maxillary lyrifissure rounded and situated submedially; posterior maxillary lyrifissure rounded. Chaetotaxy of coxae I-IV: ca. 30: ca. 30: ca. 40: ca. 80.

Legs: junction between femora and patellae I and II strongly oblique to long axis; junction between femora and patellae III and IV very angulate; femora III and IV much smaller than patellae III and IV; femur + patella of leg IV $4.15 \times$ longer than broad; patella and tibia III and IV without pseudotactile setae (Figure 47); tarsi III and IV without tactile seta (Figure 47); tarsi with single raised slit sensillum; subterminal tarsal setae arcuate and acute; claws not modified; arolium shorter than claws.

Abdomen: tergites II-X and sternites IV-X with full medial suture line, tergite I with partial suture line (Figures 40-42). Tergal chaetotaxy: 25: 29: 31: 34: 33: 34: 31: 33: 30: 28: 16: 2; setae strongly dentate. Sternal chaetotaxy: ca. 80: (4) ca. 56 [7 + 6] (4): (4) 14 (4): 25 : 28: 32: 30: 28: 21: 12: 2. Pleural membrane irregularly longitudinally striate; without setae.

Genitalia: of typical chernetid morphology.

Dimensions (mm): syntype male (BMNH 1893.12.17.-), followed by other syntype male (when measured) in parentheses: Body length 4.42 (4.16). Pedipalps: trochanter $0.800 / 0.570(0.830-0.535)$, femur $1.350 / 0.570$ $(1.360 / 0.575)$, patella $1.375 / 0.660(1.410 / 0.685)$, chela (with pedicel) 2.330/0.880 (2.440/0.900), chela (without pedicel) 2.130 (2.255), hand (without pedicel) length 1.020 (1.040), movable finger length 1.150 (1.230). Chelicera $0.500 / 0.225$, movable finger length 0.360 . Carapace 1.410/1.525 (1.370/1.620). Leg I: femur $0.510 / 0.355$, patella $0.770 / 0.290$, tibia $0.795 / 0.18$, tarsus $0.685 / 0.155$. Leg IV: femur + patella $1.390 / 0.335$, tibia $1.17 / 0.200$, tarsus $0.830 / 0.160$.

\section{REMARKS}

With (1905) described Chelifer australiensis from two specimens allegedly collected from Queensland. Judson (1997) suggested that the actual type locality may be Gerringong, New South Wales, based on information derived from the Natural History Museums accessions register. This discrepancy may never be resolved, at least until the precise distribution of this species can be ascertained. With (1905) did not designate a holotype, so both specimens are regarded as syntypes (Judson 1997). One of the males was dissected by With (1905), with legs I and IV mounted on a microscope slide (Judson 1997), and the right chela loose in the vial; the left chelicera appears to be missing. This specimen was used as the primary specimen in the above description, while the other undissected specimen was imaged for Figures $40-42$.

\section{ACKNOWLEDGEMENTS}

I am very grateful to Janet Beccaloni (BMNH) for the loan of the type specimens of Chelifer australiensis, Karl Brennan, Melinda Moir, Chris Reid and Penny
Gullan for bringing the specimens of Balgachernes occultus to my attention, Melinda Moir for comments on a draft of the manuscript, and Catalina Romero and Māra Blosfelds for assistance in the field. I also wish to thank the two anonymous referees for their constructive comments on the manuscript.

\section{REFERENCES}

Aguiar, N.O. and Bührnheim, P.F. (1998). Phoretic pseudoscorpions associated with flying insects in Brazilian Amazônia. Journal of Arachnology 26: 452-459.

Banks, N. (1901). Some spiders and other Arachnida from southern Arizona. Proceedings of the United States National Museum 23: 581-590.

Beier, M. (1932). Pseudoscorpionidea II. Subord. C. Cheliferinea. Tierreich 58: i-xxi, 1-294.

Beier, M. (1933). Revision der Chernetidae (Pseudoscorp.). Zoologische Jahrbücher, Abteilung für Systematik, Ökologie und Geographie der Tiere 64: 509-548.

Beier, M. (1937). Neue ostasiatische Pseudoscorpione aus dem Zoologischen Museum Berlin. Mitteilung aus dem Zoologischen Museum in Berlin 22: 268-279.

Beier, M. (1940). Die Pseudoscorpionidenfauna der landfernen Inseln. Zoologische Jahrbücher, Abteilung für Systematik, Ökologie und Geographie der Tiere 74: 161-192.

Beier, M. (1948a). Phoresie und Phagophilie bei Pseudoscorpionen. Österreichische Zoologische Zeitschrift 1: 441-497.

Beier, M. (1948b). Über Pseudoscorpione der australischen Region. Eos, Madrid 24: 525-562.

Beier, M. (1954). Eine Pseudoscorpioniden-Ausbeute aus Venezuela. Memorie del Museo Civico di Storia Naturale di Verona 4: 131-142.

Beier, M. (1964a). Die Pseudoscorpioniden-Fauna Chiles. Annalen des Naturhistorischen Museums in Wien 67: 307-375.

Beier, M. (1964b). Further records of Pseudoscorpionidea from the Solomon Islands. Pacific Insects 6: 592-598.

Beier, M. (1965). Die Pseudoscorpioniden Neu-Guineas und der benachbarten Inseln. Pacific Insects 7: 749-796.

Beier, M. (1966a). On the Pseudoscorpionidea of Australia. Australian Journal of Zoology 14: 275-303.

Beier, M. (1966b). Zur Kenntnis der Pseudoscorpioniden-Fauna Neu-Seelands. Pacific Insects 8: 363-379.

Beier, M. (1967). Some Pseudoscorpionidea from Australia, chiefly from caves. Australian Zoologist 14: 199-205.

Beier, M. (1969). Neue Pseudoskorpione aus Australien. Annalen des Naturhistorischen Museums in Wien 73: 171-187.

Beier, M. (1974). Brasilianische Pseudoscorpione aus dem Museum in Genf. Revue Suisse de Zoologie 81: 899-909.

Beier, M. (1976). The pseudoscorpions of New Zealand, Norfolk and Lord Howe. New Zealand Journal of Zoology 3: 199246.

Benedict, E.M. and Malcolm, D.R. (1982). Pseudoscorpions of the family Chernetidae newly identified from Oregon (Pseudoscorpionida, Cheliferoidea). Journal of Arachnology 10: 97-109.

Brennan, K.E.C., Moir, M.L. and Wittkuhn, R.S. (2011). Fire refugia: The mechanism governing animal survivorship within a highly flammable plant. Austral Ecology 36 2: 131-141.

Brown, R.W. (1956). Composition of scientific words. 882 pp. (Smithsonian Institution Press: Washington, D.C.). 
Chamberlin, J.C. (1924). Hesperochernes laurae, a new species of false scorpion from California inhabiting the nest of Vespa. Pan-Pacific Entomologist 1: 89-92.

Chamberlin, J.C. (1931). The arachnid order Chelonethida. Stanford University Publications, Biological Sciences 7(1): $1-284$.

Durden, L.A. (1991). Pseudoscorpions associated with mammals in Papua New Guinea. Biotropica 23: 204-206.

Ellingsen, E. (1910). Die Pseudoskorpione des Berliner Museums. Mitteilung aus dem Zoologischen Museum in Berlin 4: 357-423.

Esser, J. (2011). Dendrochernes cyrneus (Arachnida: Pseudoscorpiones: Chernetidae) in Brandenburg. Arachnologische Mitteilungen 42: 12-15.

Feio, J.L.d.A. (1960). Consideraciones sobre Chernetinae con la descripcion de Maxchernes birabeni genero y especies neuvos (Arachnida, Pseudoscorpiones). Neotropica 5: 71-82.

Finlayson, G.R., Madani, G., Dennis, G. and Harvey, M. (2015). First reported observation of phoresy of pseudoscorpions on an endemic New Zealand mammal, the lesser shorttailed bat, Mystacina tuberculata. New Zealand Journal of Zoology 42: 298-301.

Gärdenfors, U. and Wilander, P. (1995). Ecology and phoretic habits of Anthrenochernes stellae (Pseudoscorpionida, Chernetidae). Bulletin of the British Arachnological Society 10: $28-30$.

Harvey, M.S. (1992a). A new genus of myrmecophilous Chernetidae from southern Australia (Pseudoscorpionida). Records of the Western Australian Museum 15: 763-775.

Harvey, M.S. (1992b). The phylogeny and classification of the Pseudoscorpionida (Chelicerata: Arachnida). Invertebrate Taxonomy 6: 1373-1435.

Harvey, M.S. (1995). Barbaraella gen. nov. and Cacoxylus Beier (Pseudoscorpionda: Chernetidae), two remarkable sexually dimorphic pseudoscorpions from Australasia. Records of the Western Australian Museum, Supplement 52: 199-208.

Harvey, M.S. (2013). Pseudoscorpions of the World, version 3.0. Western Australian Museum, Perth. http://museum. wa.gov.au/catalogues-beta/pseudoscorpions. Accessed on 25 February 2018.

Harvey, M.S., Ratnaweera, P.B., Udagama, P.V. and Wijesinghe, M.R. (2012). A new species of the pseudoscorpion genus Megachernes (Pseudoscorpiones: Chernetidae) associated with a threatened Sri Lankan rainforest rodent, with a review of host associations of Megachernes. Journal of Natural History 46: 2519-2535.

Harvey, M.S. and Volschenk, E.S. (2007). A review of some Australasian Chernetidae: Sundochernes, Troglochernes and a new genus (Pseudoscorpiones). Journal of Arachnology 35: 238-277.

Harvey, M.S. and Wynne, J.J. (2014). Troglomorphic pseudoscorpions (Arachnida: Pseudoscorpiones) of northern Arizona, with the description of two new short-range endemic species. Journal of Arachnology 42: 205-219.

Hentschel, E. and Muchmore, W.B. (1989). Cocinachernes foliosus, a new genus and species of pseudoscorpion (Chernetidae) from Mexico. Journal of Arachnology 17: 345-349.

Hoff, C.C. (1949). The pseudoscorpions of Illinois. Bulletin of the Illinois Natural History Survey 24: 407-498.

Holmen, M. and Scharff, N. (2008). Anthrenochernes stellae Lohmander, 1939 - status in Denmark for a new species on the EC Habitats Directive (Arachnida, Pseudoscorpiones). Entomologiske Meddelelser- Entomologisk Forening Kobenhavn 76: 55-68.

Jones, P.E. (1980). The ecology and distribution of the pseudoscorpion Dendrochernes cyrneus (L. Koch) in Great Britain. Proceedings and Transactions of the British Entomological and Natural History Society 1980: 33-37.
Judson, M.L.I. (1997). Catalogue of the pseudoscorpion types (Arachnida: Chelonethi) in the Natural History Museum, London. Occasional Papers on Systematic Entomology 11: $1-54$.

Judson, M.L.I. (2007). A new and endangered species of the pseudoscorpion genus Lagynochthonius from a cave in Vietnam, with notes on chelal morphology and the composition of the Tyrannochthoniini (Arachnida, Chelonethi, Chthoniidae). Zootaxa 1627: 53-68.

Koch, L. and Keyserling, E. (1885). Die Arachniden Australiens. Vol. 2. (Bauer und Raspe: Nürnberg).

Mahnert, V. (1984). Pseudoscorpions (Arachnida) récoltés durant la mission spéologique espagnole au Pérou en 1977. Revue Arachnologique 6: 17-28.

Mahnert, V. (1994). New chernetid pseudoscorpions (Pseudoscorpionida: Chernetidae) from Venezuela and Brazil, with remarks on the genus Ancalochernes Beier. Revue Suisse de Zoologie 101: 829-838.

Mahnert, V. (2009). Attaleachernes gen. nov., a new chernetid genus from palm trees in the Brazilian Pantanal (Pseudoscorpiones: Chernetidae). Contributions to Natural History (Bern) 12: 921-930.

Mahnert, V. and Andrade, R.d. (1998). Description of a new troglophilous species of the genus Maxchernes Feio, 1960 (Pseudoscorpiones, Chernetidae) from Brazil (São Paulo State). Revue Suisse de Zoologie 105: 771-775.

Muchmore, W.B. (1971). Phoresy by North and Central American pseudoscorpions. Proceedings of the Rochester Academy of Science 12: 79-97.

Muchmore, W.B. (1972). Observations on the classification of some European chernetid pseudoscorpions. Bulletin of the British Arachnological Society 2: 112-115.

Muchmore, W.B. (1974). Clarification of the genera Hesperochernes and Dinocheirus (Pseudoscorpionida, Chernetidae). Journal of Arachnology 2: 25-36.

Muchmore, W.B. (1984). The pseudoscorpions described by R.V. Chamberlin (Pseudoscorpionida, Olpiidae and Chernetidae). Journal of Arachnology 11: 353-362.

Pfeiler, E., Bitler, B.G., Castrezana, S., Matzkin, L.M. and Markow, T.A. (2009). Genetic diversification and demographic history of the cactophilic pseudoscorpion Dinocheirus arizonensis from the Sonoran Desert. Molecular Phylogenetics and Evolution 52: 133-141.

Poinar, G.O., Jr, Ćurčić, B.P.M. and Cokendolpher, J.C. (1998). Arthropod phoresy involving pseudoscorpions in the past and present. Acta Arachnologica 47: 79-96.

Turienzo, P., Iorio, O.d. and Mahnert, V. (2010). Global checklist of pseudoscorpions (Arachnida) found in birds' nests. Revue Suisse de Zoologie 117: 557-598.

Vitali-di Castri, V. (1972). El genero sudamericano Gigantochernes (Pseudoscorpionida, Chernetidae) con descripcion de dos nuevas especies. Physis, Buenos Aires 31: $23-38$.

With, C.J. (1905). On Chelonethi, chiefly from the Australian region, in the collection of the British Museum, with observations on the "coxal sac" and on some cases of abnormal segmentation. Annals and Magazine of Natural History (7) 15: 94-143, 328.

Zeh, D.W. and Zeh, J.A. (1992a). Emergence of a giant fly triggers phoretic dispersal in the neotropical pseudoscorpion, Semeiochernes armiger (Balzan) (Pseudoscorpionida: Chernetidae). Bulletin of the British Arachnological Society 9: $43-46$.

Zeh, D.W. and Zeh, J.A. (1992b). Failed predation or transportation? Causes and consequences of phoretic behavior in the pseudoscorpion Dinocheirus arizonensis (Pseudoscorpionida: Chernetidae). Journal of Insect Behavior 5: 37-49.

MANUSCRIPT RECEIVED 23 APRIL 2018; ACCEPTED 22 JUNE 2018. 